\title{
Hairs of wild Felis silvestris silvestris and domestic Felis catus - are they distinctive after all? (Carnivora: Felidae)
}

Srst kočky divoké (Felis silvestris silvestris) a kočky domácí (Felis catus) - jsou prŕtomny rozdíly či nikoli? (Carnivora: Felidae)

\section{Lisa LEHMANN \& Clara STEFEN}

Senckenberg Naturhistorische Sammlungen Dresden, Königsbrücker Landstraße 159, 01109 Dresden; lisalehmann93@web.de; clara.stefen@senckenberg.de

\begin{abstract}
This study addressed the question whether it is possible to clearly differentiate between wild and tabby domestic cats on the basis of hairs (guard hairs in particular). The colour banding pattern of individual hairs is studied in this context for the first time. Also, hair length and width, as well as parameters of the hair cuticle were checked for differences, as it is well known that wild cats have long hairs and a fine, silky fur. Several banding patterns were observed, some shared between both cat forms, but with different frequencies. But this is not enough for species differentiation and more specimens need to be studied to get a better idea of the variation in this trait. The cuticle pattern even in the same region of the hairs (medium and shield-free part of the hair shaft) varies considerably and statistically significant differences were found only for few measured parameters: hair length, hair width and scale perimeter. Nevertheless, even most of them are not sufficient to determine wild or domestic cats. However, as expected, the hairs of wild cats are statistically significantly longer than those of tabby domestic cats, and hairs longer than $50 \mathrm{~mm}$ can be clearly attributed to wild cats.
\end{abstract}

Key words. Felis silvestris, Felis catus, primary hair, colour banding pattern, hair length, hair width, cuticle structure, cuticle parameters.

\section{INTRODUCTION}

The wild cat (Felis silvestris Schreber, 1777) has Palaearctic and Afrotropical distributions, from Scotland to South Africa and from Morocco to southern China (CORBET 1979, DriscolL et al. 2007). Based especially on coat colour, body size and robustness, three groups are distinguished: silvestris group (European wildcat), lybica group (African wildcat), and ornata group (Asian or Indian wildcat) (KITCHENER 1991, WozENCRAFT 1993). Recently, however, Felis lybica Forster, 1780 (including $F$. lybica ornata Gray, 1831 as a subspecies) and F. silvestris have been differentiated at the species level and $F$. silvestris with three subspecies is restricted to Europe (KITCHENER et al. 2017). The domestic cat (Felis catus Linnaeus, 1758) probably originated from the African wild cat and was then distributed around the world by humans (Clutton-Brock 1999, Driscoll et al. 2009). The European wildcat is under special protection in Europe, listed in the Habitats Directive (Council Directive 92/43/EEC) adopted in 1992 by the European Union. Therefore, protection and management of the species are important and in this context the possibility to document the occurrence and distribution of wild cats has high 
priority. The differentiation of wild cats from wild coloured or tabby domestic cats might be difficult, although a bulk of literature deals with their distinction based on morphology (e. g. Schreber 1777, Piechocki 1990, Daniels et al. 1998, Beaumont et al. 2001, Stefen \& Görner 2009). In recent years mainly, molecular techniques are used to distinguish both cats (RANDI et al. 2001, Nussberger et al. 2013, Steyer et al. 2016, Mattucci et al. 2019), but this does not render morphological differentiation dispensable.

Generally, mainly cranial and dental morphology are studied to differentiate between species, and less often visceral and physiological traits; in case of wild and domestic cat these are skull and intestine, but also pelage colour and colour patterning (e. g. RaGNi \& Possenti 1996). But also, the morphological study of hairs and their cuticle structure is used in mammal taxon identification, often but not only, to analyse prey items (e. g. De Mairens 2006, Dharaiya \& Soni 2012, Tóth 2017, Lagos \& Bárcena 2018, SARi \& ArpaciK 2018).

Already in the early descriptions of wild cats, the longer and finer hair compared to domestic cats is usually mentioned (SCHREBER 1777). Generally, the hair of wild cats is considered significantly longer (Vogt 1984, PIECHOCKi 1990) than that of domestic cats, but the ranges overlap considerably (Vogt 1984). MEYer et al. (1997b) studied hairs of several domestic animals and their wild relatives and concluded that it is not possible to distinguish structurally the hair of wild mammals and the derived domestic forms. Nevertheless, here we address the question whether wild and domestic cats (wild coloured or tabby form only) could be differentiated on the basis of hair length, width, colour banding pattern, and/or cuticle parameters. The rationale for the study is that the banding pattern has not been documented so far, the hair length is long supposed to be different and the European wildcat is not considered the species from which domestic cats derived.

\section{MATERIAL AND METHODS}

Skins from a total of 18 wild and 20 domestic cats, determined on the basis of morphological features of the pelage and in most cases additional cranial features, were studied in the mammal collection in the Senckenberg Naturhistorische Sammlungen Dresden, Museum für Tierkunde (MTD). Following MeYER et al. (1997a) recommendation that the same type of hair from the same body region should be studied, a sample was taken from each animal on the left and right side of the back at the level of the hip (dorsolateral body region), so that a total of 76 samples were available. Three to eight guard hairs (primary hairs) including hair roots were removed using tweezers. It was ensured that the hair was not damaged or broken off by the tweezers. At first the length of hairs was measured using calipers and the banding patterns were recorded. The banding pattern of 12 samples was not analyzed because they were not wild coloured domestic cats.

As the tip of guard hairs has a very variable cuticle pattern, and the base region often has a relatively uniform character (MEYER et al. 2002b), only the medium and shield-free part of the hair shaft was used for the study by scanning electron microscopy (SEM). To do this, a whole hair of a sample was glued to a metal stamp and metallized with a gold-platinum alloy. The selected area was photographed. The cuticle structure was described according to TEERINK (1991). In the selected area, the hair width was measured as well as the height and width of five cuticle scales of a hair using the program SmartTIFF V1.0.0.9. Furthermore, the surface area and the circumference of five cells of a sample were determined with the free software ImageJ 1.50i (https://imagej.net/). The measurements were made using the photos.

Microsoft Office Excel 2007 and the program STATGRAPHICS Centurion 18 (version 18.1.06) were used for statistical evaluation of the data. Descriptive statistics were calculated and box-and-whisker plots and histograms were created. The data series were then examined for normal distribution using the Shapiro-Wilk-Test. The Mann-Whitney-Test and the Kolmogorow-Smirnow-Test were then used to see if there are significant differences between wild and domestic cats. 


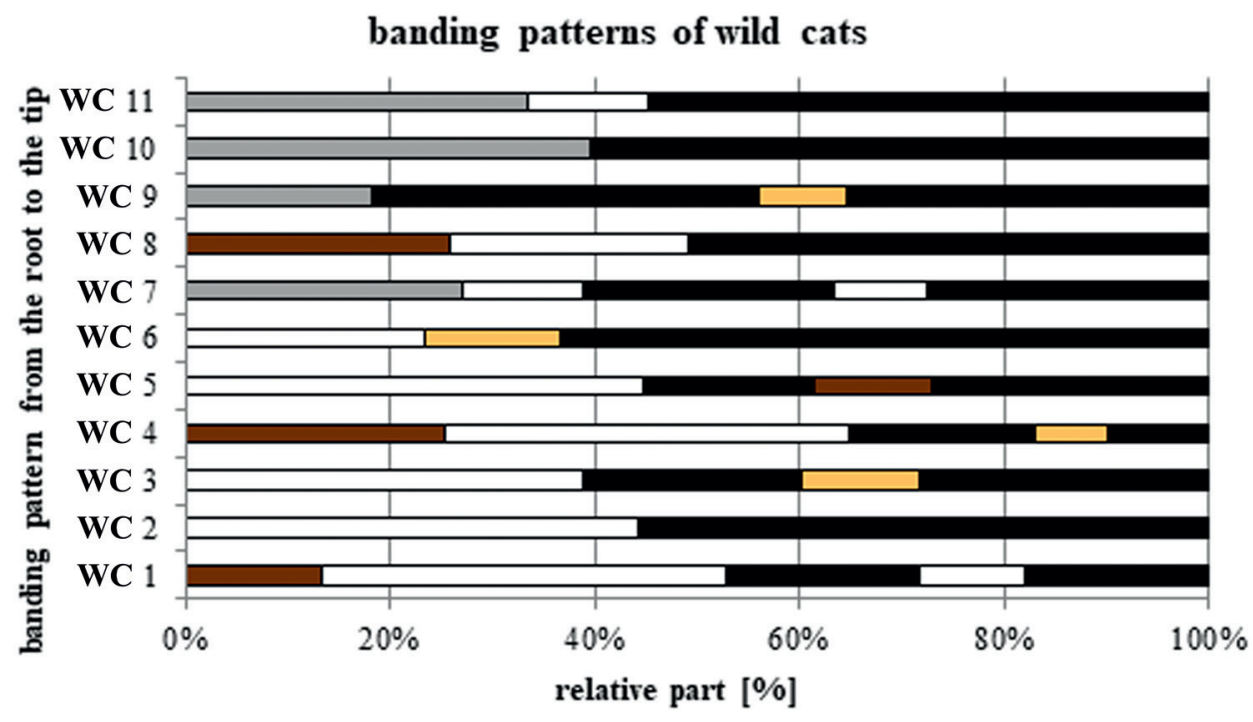

banding patterns of domestic cats

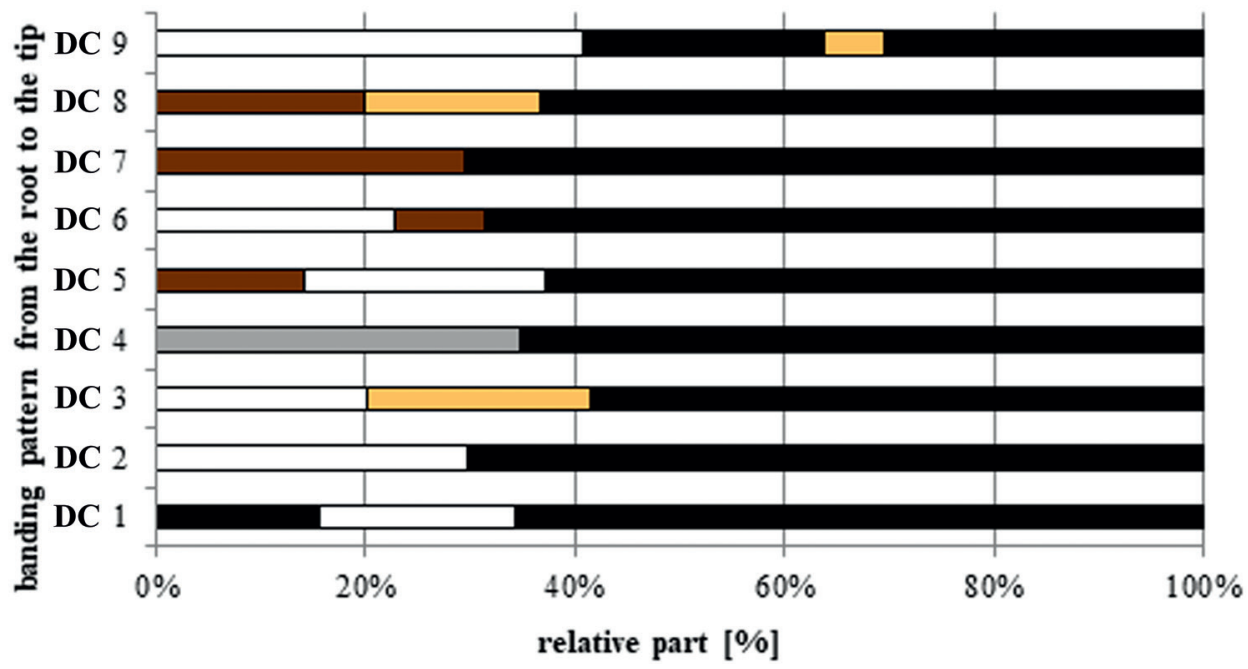

Fig. 1. Schematic illustration of banding patterns of hairs of wild (WC, above) and domestic cats (DC, below). The root of the hairs is to the left, the tip to the right. Hairs are drawn in the same length and the relative length of differently coloured parts is given. White bars indicate white or light creamy hair, black bars indicate black hair, beige, brown and grey bars indicate beige, brown and grey hair.

Obr. 1. Schematické zobrazení vzorů pruhování na chlupech kočky divoké (WC, nahoře) a domácí (DC, dole). Kořen chlupu je vlevo, špička chlupu vpravu. Chlupy jsou zakresleny ve stejné délce a zobrazena je relativní délka odlišně zbarvených úseků. Bílé pruhy označují bílé nebo světle krémově zbarvené úseky, černé pruhy označují černé úseky, béžové, hnědé a šedé pruhy označují béžové, hnědé a šedé úseky chlupu. 
Table 1. Frequency and proportion of the different banding patterns of individual hairs of the wild cat (WC) samples

Tab. 1 Četnost a podíl odlišných vzorů pruhování jednotlivých chlupů ze vzorků kočky divoké (WC)

\begin{tabular}{lcc}
\hline $\begin{array}{l}\text { banding pattern number } \\
\text { číslo vzorce pruhování }\end{array}$ & $\begin{array}{c}\text { count } \\
\text { počet }\end{array}$ & $\begin{array}{r}\text { share in all wild cat hair samples [\%] } \\
\text { podíl všech vzorků koček divokých [\%] }\end{array}$ \\
\hline WC 1 & 1 & 2.8 \\
WC 2 & 3 & 8.3 \\
WC 3 & 16 & 44.4 \\
WC 4 & 1 & 2.8 \\
WC 5 & 5 & 13.9 \\
WC 6 & 2 & 5.6 \\
WC 7 & 2 & 5.6 \\
WC 8 & 1 & 2.8 \\
WC 9 & 3 & 8.3 \\
WC 10 & 1 & 2.8 \\
WC 11 & 1 & 2.8 \\
\hline
\end{tabular}

\section{RESULTS}

The hairs of wild cats are usually clearly banded, with the exception of the hairs of the throat, where short pure white or creamy coloured hair can be found. The colour banding of the hairs of wild cats and of tabby domestic cats already vary within species. Fig. 1 shows the observed banding patterns for wild and domestic cats. Altogether 11 different colour banding patterns or sequences were identified in the studied wild cats and nine in the domestic cats. The sequence "white-black-beige-black" (described from hair root to tip) was the most frequent one in wild cats (16 samples, around 44\%). The second most common sequence was "white-black-brownblack" (five samples, almost 14\%) (Table 1). In the domestic cats, the sequence "white-black" could be seen in seven samples, which corresponds to a share of $17.5 \%$ in all domestic cat samples and $25 \%$ in the wild coloured domestic cat samples (Table 2). The patterns "blackwhite-black" and "gray-black" were most frequently recognized in five samples each. This corresponds to a relative share of $12.5 \%$ and almost $18 \%$, respectively. It is striking that the sequence "white-black-beige-black" was most common in the wild cats and occurred only once in the domestic cats.

Examples of the cuticle pattern of wild and domestic cats are illustrated in Figs. 2 and 3 and it is obvious that they are very similar in appearance. In most cases both have scales with

Fig. 2. Cuticula structure in the middle of guard hairs of wild cats as seen by scanning electron microscopy. Scale bar $=10 \mu \mathrm{m}$, tip of the hair is to the right. Collection number in MTD of the specimens used: (a) B1288, (b) B1291, (c) B13980, (d) B13983, (e) B16480, (f) B16932, (g) B24383, (h) B27908.

Obr. 2. Struktura kutikuly ve střední části pesíku kočky divoké zobrazená rastrovacím elektronovým mikroskopem. Měřítko $10 \mu \mathrm{m}$, vrchol chlupu napravo. Evidenční čísla vzorků: (a) B1288 levá strana, (b) B1291 pravá strana, (c) B13980 levá strana, (d) B13983 levá strana, (e) B16480 pravá strana, (f) B16932 pravá strana, (g) B24383 levá strana, (h) B27908 pravá strana. 


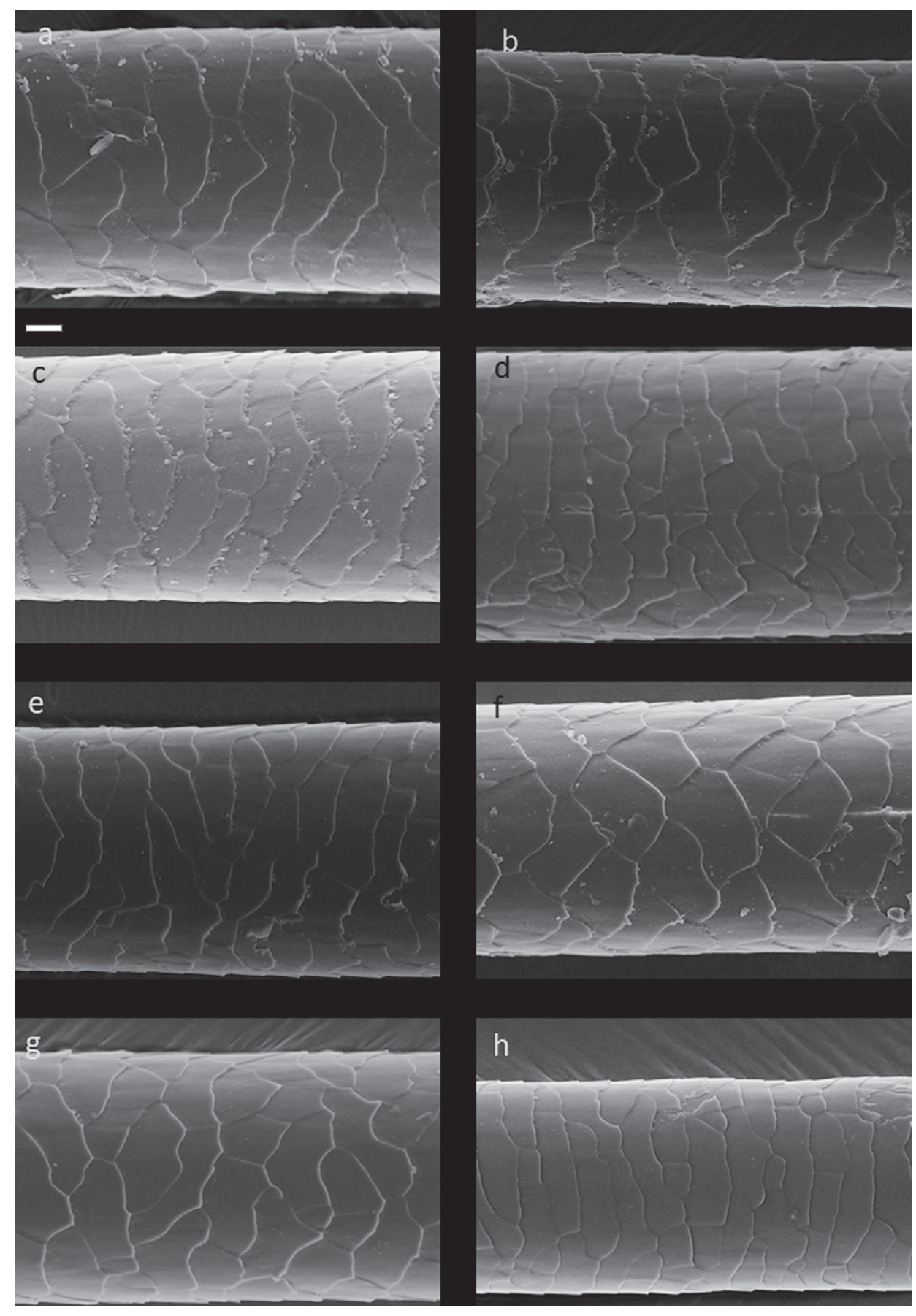


Table 2. Frequency and proportion of the different banding patterns of individual hairs of the domestic cat (DC) samples

Tab. 2 Cetnost a podíl odlišných vzorů pruhování jednotlivých chlupů ze vzorků kočky domácí (DC)

\begin{tabular}{lccc}
\hline banding pattern number & count & $\begin{array}{c}\text { share in all domestic } \\
\text { cat hair samples [\%] } \\
\text { podíl všech vzorkü } \\
\text { koček domácích [\%] }\end{array}$ & $\begin{array}{r}\text { share in tabby or wild coloured } \\
\text { domestic cat hair samples [\%] } \\
\text { podíl všech vzorkú mourova- } \\
\text { tých koček domácích [\%] }\end{array}$ \\
\hline DC 1 & počet & 12.5 & 17.9 \\
DC 2 & 5 & 17.5 & 25.0 \\
DC 3 & 7 & 2.5 & 3.6 \\
DC 4 & 1 & 12.5 & 17.9 \\
DC 5 & 5 & 10 & 14.3 \\
DC 6 & 4 & 2.5 & 3.6 \\
DC 7 & 1 & 7.5 & 10.7 \\
DC 8 & 3 & 2.5 & 3.6 \\
DC 9 & 1 & 2.5 & 3.6 \\
not tabby or wild coloured & 1 & 30 & - \\
/ není mourování & 12 & & \\
\hline
\end{tabular}

a regular smooth rim, but there are some exceptions in the middle of the hair. The scales appear mostly regular. Scales are often longer than the hair width, which made measurements difficult and lead to few data for scale width. The cuticle patterns vary considerably within one species, which renders a purely optical distinction impossible. Therefore, some cuticle parameters were statistically analyzed and tested for differences.

The descriptive statistics of hair length and width and scale parameters are given in Table 3 . The guard hairs of wild cats are statistically significantly longer $(p \leq 0.05)$ than those of domestic cats (mean for wild cats $55.77 \mathrm{~mm}$ [ $\mathrm{n}=108]$ and domestic cats $36.87 \mathrm{~mm}$ [n=108], Table 3, Figs. 4, 5), but the variance is large for both. Only hairs more than $50 \mathrm{~mm}$ in length can clearly be associated with wild cats. The width of the hairs was found to be significantly different between the two cats (Figs. 4, 5). Statistically significant differences were also found for the scale perimeter (Figs. 4, 5), but not for the other scale parameters: width, height and scale area (Figs. 4, 5).

Fig. 3. Cuticula structure in the middle of guard hairs of domestic cats as seen by scanning electron microscopy. Scale bar $=10 \mu \mathrm{m}$, tip of the hair is to the left. Collection number in MTD of the specimens used: (a) B11874, (b) B12934 right side, (c) B12934 left side, (d) B14830 right side, (e) B14830 right side, (f) B27020 right side, (g) B27020, (h) B28055.

Obr. 3. Struktura kutikuly ve střední části pesíku kočky domácí zobrazená rastrovacím elektronovým mikroskopem. Měrítko $10 \mu \mathrm{m}$, vrchol chlupu nalevo. Evidenční čísla vzorků: (a) B11874 pravá strana, (b) B12934 levá strana, (c) B12934 pravá strana, (d) B14830 levá strana, (e) B14830 pravá strana, (f) B27020 levá strana, (g) B27020, (h) B28055. 


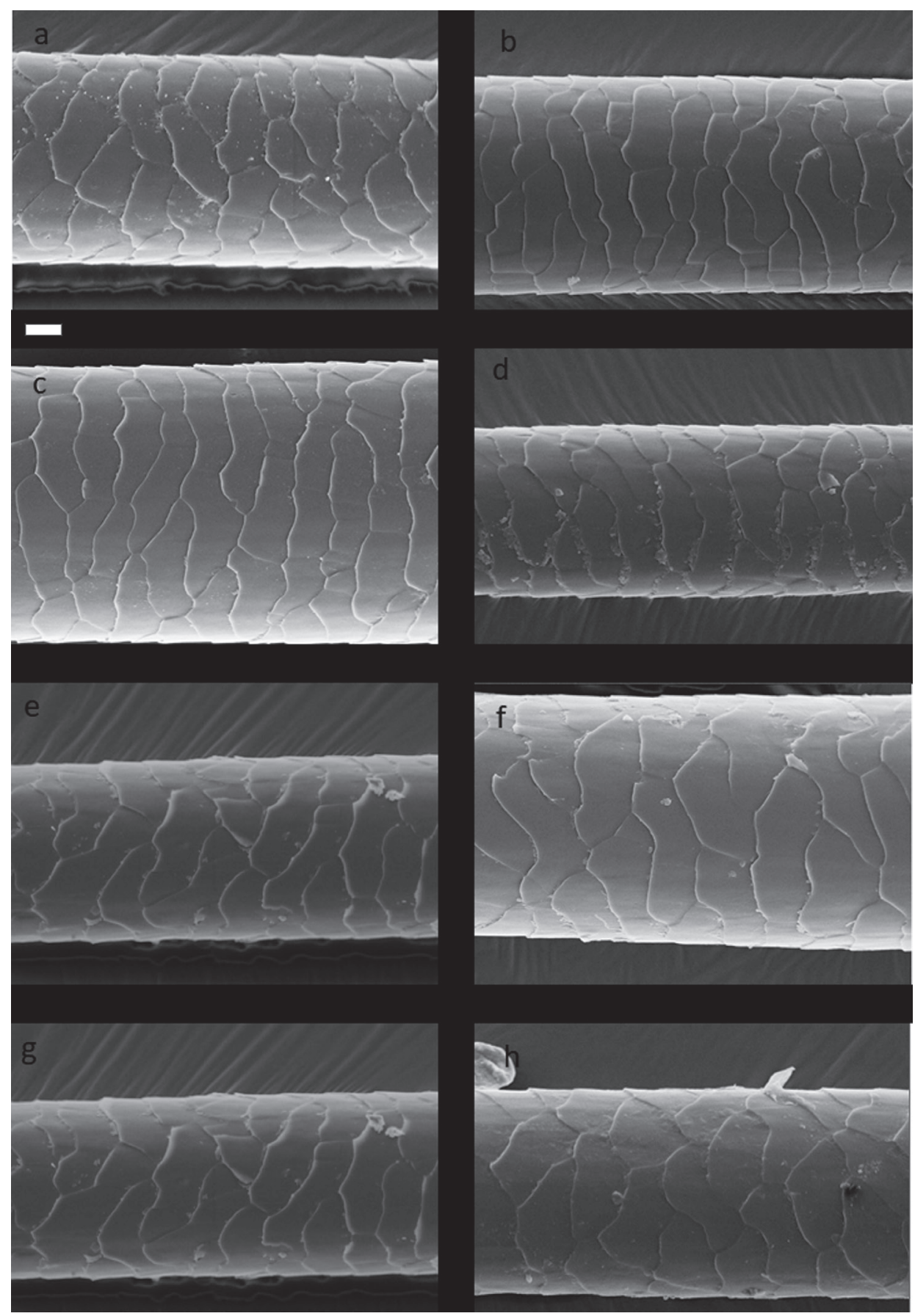


Table 3. Descriptive statistics of the measured hair length and hair width of wild (WC) and domestic cats DC); $\mathrm{n}$ - number, min - minimum, max - maximum, SD - standard deviation, SE - standard error, $\mathrm{CV}$ - coefficient of variation

Tab. 3 Popisná statistika naměřené délky a šířky chlupů kočky divoké (WC) a kočky domácí (DC); hair length - délka chlupu, hair width - šířka chlupu, scale height - výška šupiny, scale width - šiřka šupiny, scale area - plocha šupiny, scale perimeter - obvod šupiny, $\mathrm{n}$ - počet, mean - průměr, min - minimum, $\max$ - maximum, $\mathrm{SD}$ - směrodatná odchylka, SE - směrodatná chyba, CV - variační koeficient

\begin{tabular}{lrrrrrrrr}
\hline character / znak & $\mathrm{n}$ & mean & \multicolumn{1}{c}{$\min$} & $\max$ & median & \multicolumn{1}{c}{ SD } & SE & CV \\
\hline WC hair length $[\mathrm{mm}]$ & 108 & 55.77 & 43.60 & 71.03 & 55.30 & 5.64 & 0.54 & 0.10 \\
DC hair length $[\mathrm{mm}]$ & 108 & 36.87 & 16.76 & 48.51 & 37.42 & 11.20 & 0.62 & 0.18 \\
WC hair width $[\mu \mathrm{m}]$ & 36 & 67.47 & 41.37 & 92.25 & 70.29 & 6.47 & 1.87 & 16.60 \\
DC hair width $[\mu \mathrm{m}]$ & 40 & 59.62 & 34.38 & 110.6 & 58.63 & 16.12 & 2.55 & 27.05 \\
WC scale heigth $[\mu \mathrm{m}]$ & 180 & 11.25 & 5.36 & 21.41 & 10.56 & 3.48 & 0.26 & 30.93 \\
DC scale heigth $[\mu \mathrm{m}]$ & 200 & 11.58 & 4.73 & 26.44 & 10.87 & 3.95 & 0.28 & 34.14 \\
WC scale width $[\mu \mathrm{m}]$ & 180 & 30.10 & 11.69 & 58.01 & 28.62 & 8.42 & 0.63 & 27.96 \\
DC scale width $[\mu \mathrm{m}]$ & 200 & 29.38 & 8.28 & 65.06 & 28.75 & 8.77 & 0.62 & 29.81 \\
WC scale area $\left[\mu \mathrm{m}^{2}\right]$ & 180 & 314.28 & 104.21 & 871.56 & 302.40 & 118.94 & 8.86 & 37.84 \\
DC scale area $\left[\mu \mathrm{m}^{2}\right]$ & 200 & 293.68 & 78.22 & 583.58 & 280.87 & 90.75 & 6.42 & 30.90 \\
WC scale perimeter $[\mu \mathrm{m}]$ & 180 & 89.24 & 38.11 & 165.30 & 86.47 & 20.30 & 1.51 & 22.75 \\
DC scale perimeter $[\mu \mathrm{m}]$ & 200 & 84.97 & 42.75 & 160.58 & 82.76 & 18.68 & 1.32 & 21.98 \\
\hline
\end{tabular}

\section{DISCUSSION}

General colour and banding pattern of hairs

With the development of lure stick programs to collect hairs from cats in the field to be sent for genetic determination in the laboratory (Hupe \& SimOn 2007, Steyer et al. 2013), it might be easier, less time consuming and cheaper to identify them by sight and or microscopy (including SEM) if only the distribution of wild cats is of interest (genetic analysis might yield more than the taxonomic determination). Besides the mentioned parameters of the hairs we studied the colour banding pattern of the hairs for the first time.

Many studies show the differences between wild and domestic cats based on the coat colour (Schreber 1777, Eckstein 1919, French et al. 1988, Piechocki 1990, Stefen \& Görner 2009). Already HAMiLton (1896) summarized that the colouring of the wild cat alone is subject to a wide range of variations and KLEINSCHMIDT (1938) drew attention to the different colour gradations of wild cats from different regions. Also, colour anomalies of the wild cats are known: SLÁDEK (1976) identified partial leucism (partially white fur), total melanism (completely black fur) and total flavism (completely red fur) in two individuals each among over 500 Slovakian wild cats. The animals were identified as wild cats based on the craniological characteristics according to KRATOCHVíl (1973). Without further study, such cats are generally considered to be domestic cats and are therefore not included in collections.

In a study using coat color variation, RAGNI \& POSSENTI (1996) show growth curves indicating that the number of coat pattern variations increases with the sample size, but that the curve has an asymptotic course. Especially for the European wild cat, the number of 4 pattern variations is 
reached with less than 12 specimens; only in domestic cats more would be needed and here the curve is not so strongly asymptotic. Assuming that a similar relationship between the number of phenotypes and sample size holds for hairs in wild cats, we can consider the sample studied as sufficient. More specimens would, however, give an even better idea of the frequency of the detected banding patters. However, MeYER et al. (1997b) used 10-20 primary hairs in their study which is comparable in magnitude to the present study.
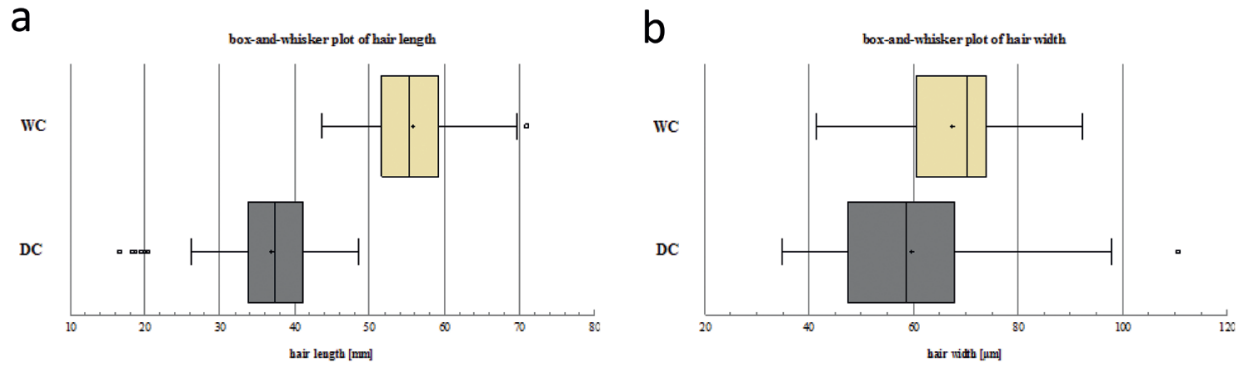

C

d
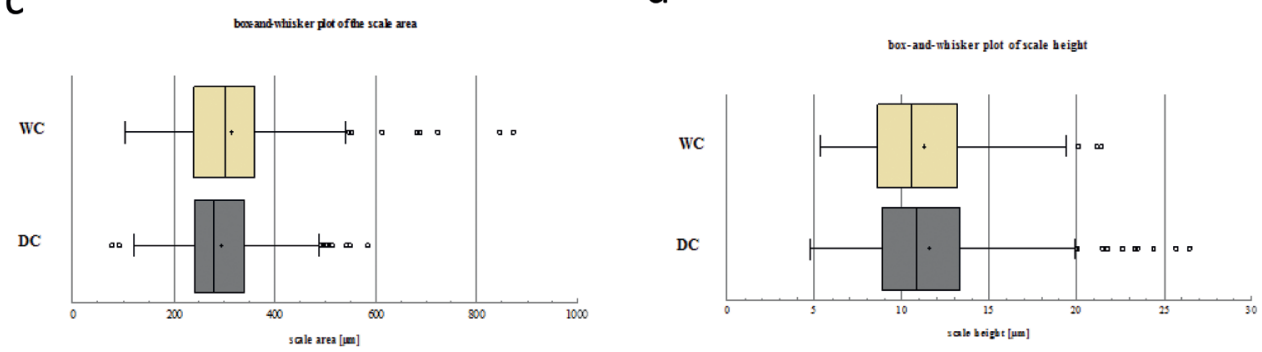

e

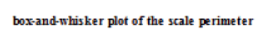

f
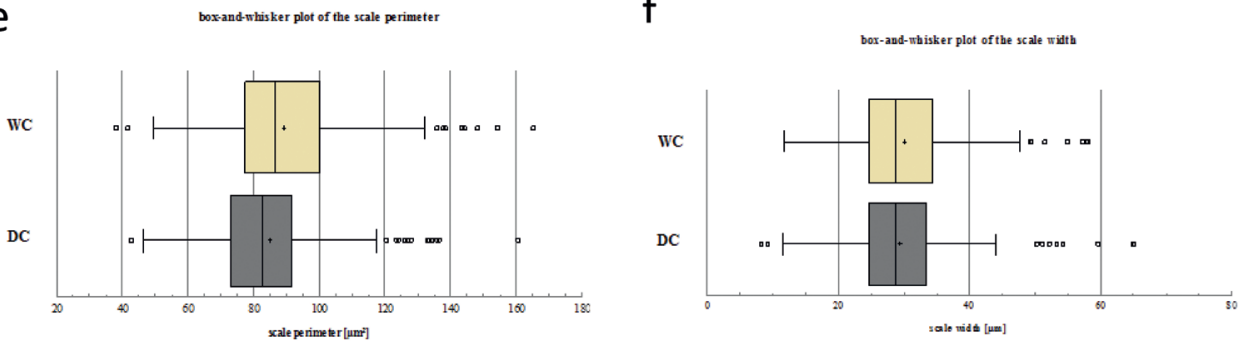

Fig. 4. Box-and-whisker plots showing the difference between wild (WC) and domestic cats (DC) in (a) hair length, (b) hair width, (c) cuticle scale area, (d) cuticle scale perimeter, (e) cuticle scale width, and (f) cuticle scale height.

Obr. 4. Krabicové diagramy ukazující rozdíly mezi kočkou divokou (WC) a domácí (DC) v (a) délce chlupů, (b) širrce chlupů, (c) velikosti kutikulárních šupin, (d) obvodu kutikulárních šupin, (e) šířce kutikulárních šupin a (f) výšce kutikulárních šupin. 
Hairs of wild as well as tabby or wild coloured domestic cats are usually banded with dark, nearly black or dark brown and whitish to beige and brown bands. Generally, the hair tip is black. This basic banding pattern can vary though, in the number of bands on the hair, in the colour of the bands and in the length of the individual bands (Fig. 1). It is worth mentioning that the colour sequences "white-black-beige-black" and "white-black-brown-black" (starting at the root towards the tip) were found much more frequently in wild than in domestic cats. However, this is by no means a criterion for clear separation of the two species. On the basis of the banding pattern alone, no distinction between the animals is possible.

\section{Length and width of hairs}

Especially on the head, neck and nape, not measured here, also the wild cat has relatively short hairs. No hair samples from long-haired domestic cats were included in the statistical analysis, as Persian cats and their hairs can be distinguished from wild cats on the basis of the colouration.

The fact that the hairs of wild cats are generally longer and very fine or silk-like has already been stated in the early descriptions of wild cats (e. g. Buffon 1773, Schreber 1777, KoHLHAAS 1794) and has been confirmed or reiterated by other authors (Table 4). MEYER et al. (2002a) support these statements and describe the fur of the wild cat as soft, dense and long. MEYER et al. (1982) determined hair lengths of 40-70 $\mathrm{mm}$ for adult wild cats and 30-50 $\mathrm{mm}$ for juvenile animals, the summer coat being approx. 20 to $30 \%$ shorter than the winter coat. The measured lengths of $43.60-71.03 \mathrm{~mm}(\mathrm{n}=108)$ herein thus correspond to the literature. A distinction between summer and winter fur was here omitted due to the lack of data on the specimens.

Lengths of $40 \mathrm{~mm}$ are specified for the primary hair of the domestic cat (TEERINK 1991). Earlier studies found hair lengths of $41 \mathrm{~mm}$ in domestic cats and $35 \mathrm{~mm}$ for the cut hair of an Angora cat (Lochte 1938). The median length of $37.42 \mathrm{~mm}$ calculated in the present work corresponds to the literature. When comparing the values of wild and domestic cat it is noticeable that in most cases the wild cat hair is longer than the domestic cat hair, but there still is an overlap of the ranges. The hair length is suitable to a limited extent only to tell the two types apart: hairs longer than $50 \mathrm{~mm}$ are associated with wild cats.

The information on the hair width of the wild cats varies widely in the literature (Table 4). The measured hair widths from 41.37 to $92.25 \mu \mathrm{m}(\mathrm{n}=36)$ herein agree with the literature. Widths of $120 \mu \mathrm{m}$ are specified for the primary hair of domestic cats (TEERINK 1991). De MeIJERE (1894) determined hair widths of $12-22 \mu \mathrm{m}$ in newborn domestic cats and diameters of $36-44 \mu \mathrm{m}$ in primary hair of the Angora cats. Guide hairs of adult Angora cats reached widths of 40-56 $\mu \mathrm{m}$. The measured values herein are between 34.38 and $110.60 \mu \mathrm{m}(\mathrm{n}=40)$. In comparison with the wild cats it becomes clear that although there are significant differences, the hair width alone is not suitable to differentiate between the two species.

\section{Cuticle structure and parameters}

Both cat forms show broad, diamond petal to broad petal scale patterns with smooth rims in the basal part of the hairs to broad petal structure scales. Differences in the cuticle structure between wild and domestic cats have been illustrated by TEERINK (1991).

Early publications dealt with the cuticle of domestic cat hair. Drawings and descriptions by Waldeyer (1884), Hofer (1914), Hausman (1924) and Schröder (1930) reveal imbricative scales that overlap. They also show that the scales at the hair base are wider than in the middle 
a

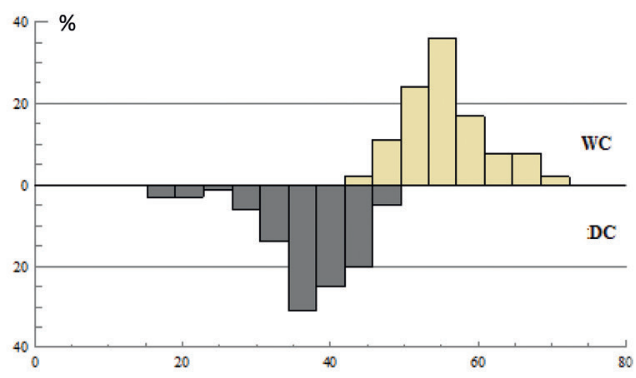

C

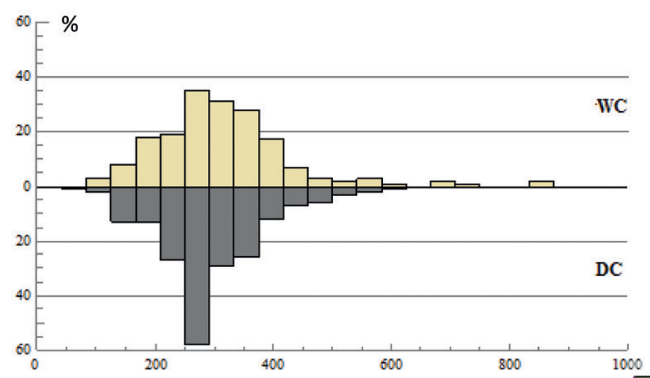

$\mathrm{e}$

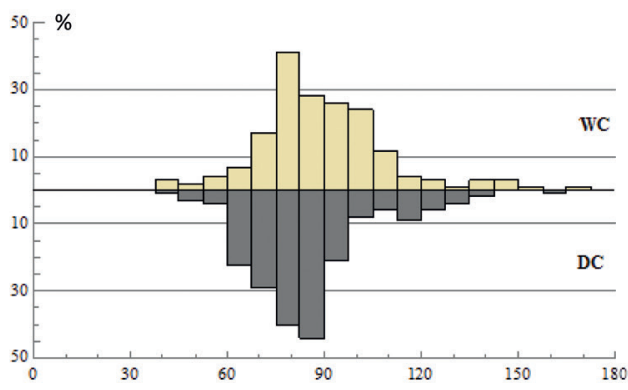

b

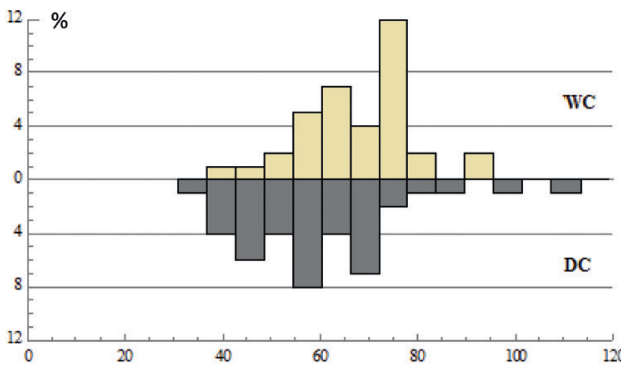

d
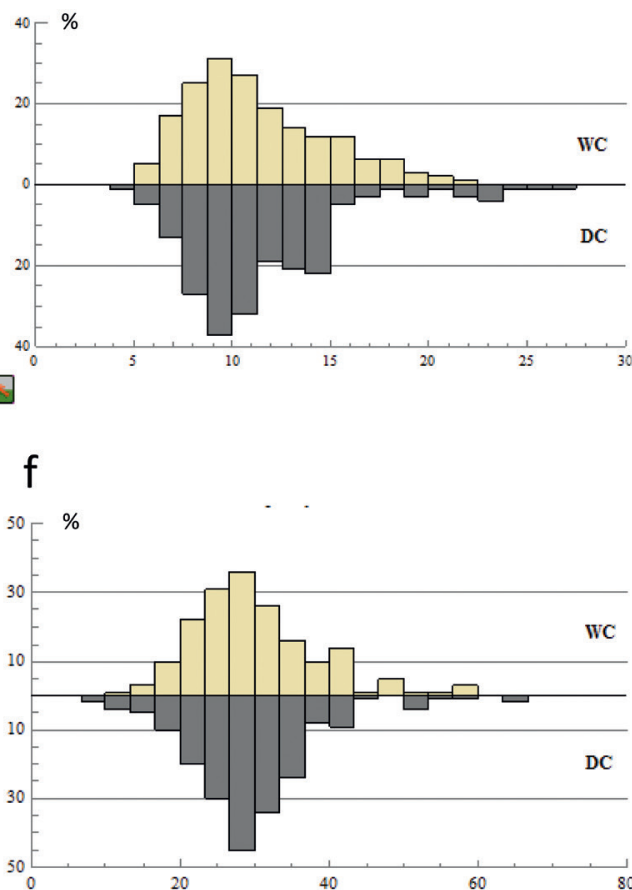

Fig. 5. Frequency of (a) hair length, (b) hair width, (c) cuticle scale area, (d) cuticle scale perimeter, (e) cuticle scale width and (f) cuticle scale height of wild (WC, yellow) and domestic cats (DC, grey).

Obr. 5. Četnost (a) délky chlupů, (b) šířky chlupů, (c) velikosti kutikulárních šupin, (d) obvodu kutikulárních šupin, (e) šířky kutikulárních šupin a (f) výšky kutikulárních šupin u kočky divoké (WC, žlutě) a kočky domácí (DC, šedě).

of the hair. In addition, irregularities in the shape and size of the scales are indicated. Hofer (1914) confirmed that the shape and arrangement of the cuticular scales of the domestic cat 
hair are very different and depend on the width of the hair. The thicker the hair, the fewer scales there are. Maybe in domestic cats, differences in the cuticle structure of hairs are only small and therefore hardly detectible as breeding of cats for different fancy colourations began only relatively recently and most domestic cats still are tabby cats.

On the first sight, the cuticle structure seemed to differ between the cat forms: The hairs of the wild cat appeared generally broader or stronger than those of the domestic cat, and the cuticle structure appeared more ordered, and coarser. However, a larger sample soon revealed that the variability is large and this impression is difficult to quantify. MEYER et al. (2002a) described the scale margins as rippled at the tip of the hair and smooth in the middle and at the base and the scale form and arrangement as irregular wave at the tip, regular wave in the middle and broad petal at the base in wild cat hairs.

Finally, the individual parameters including height, width, area and perimeter of the scales were examined. In the scale perimeter, significant differences $(\mathrm{p} \leq 0.05)$ between wild $(\mathrm{n}=180$, mean $=9.24 \mu \mathrm{m})$ and domestic cats $(n=200$, mean $=84.97 \mu \mathrm{m})$ could be determined. The other parameters are not suitable for distinguishing between the two species. MEYER et al. (2002a) indicate an average perimeter of $67 \mu \mathrm{m}$ for wild cats. No literature references were available for domestic cats so far.

Even though also the scale perimeter differs significantly between wild and domestic cats, the large range renders this feature unsuitable for differentiation.

\section{CONCLUSIONS}

The banding pattern of hairs is studied here for the first time in a small sample. The pattern "white-black-beige-black" is more common in wild than in domestic cats but more studies are needed to corroborate that. Differences in cuticle structure are few, and only the differences in the length and width of hairs as well as in the perimeter of scales are statistically significant. The hair width and the perimeter of scales are nevertheless not suitable for differentiating between wild and domestic cats, because in both cases the ranges overlap too much. Thus, in general, the statement of MEYER et al. (1997b), that no clear differentiation between wild and domesticated animals on the basis of hairs is supported here. However, guard hairs longer than $50 \mathrm{~mm}$ can clearly be attributed to wild cats. This is an additional aspect in morphological determination of hair samples and/or cadavers found.

\section{SOUHRN}

V této studii si klademe za cíl zodpovědět otázku, zda je možné jednoznačně rozlišit mezi kočkou divokou a mourovatě zbarvenou kočkou domácí na základě porovnání chlupů ze srsti (především pesíků). Vzorování v podobě barevných pruhů na jednotlivých chlupech je $\mathrm{v}$ této souvislosti studováno poprvé. Porovnávána byla délka a šiřka chlupu a rovněž vlastnosti chlupové kutikuly, protože z výsledků předchozích studií vyplývá, že kočka divoká má delší chlupy a jemnou, na omak hedvábně měkkou kožešinu. Pozorováno bylo několik odlišných vzorů pruhování, z nichž některé jsou sice sdíleny oběma taxony, ale v odlišných četnostech. Toto kriterium však není dostatečné k jednoznačnému odlišení, pro přesnější představu o variabilitě tohoto znaku bude potřeba zařadit více vzorků. Struktura kutikuly chlupu, dokonce i v rámci jedné jeho části (střední část vlasového stvolu), je velmi variabilní. Statisticky významné rozdíly byly nalezeny jen pro několik málo měřených parametrů: délka chlupu, šŕřka chlupu a obvod kutikulárních šupin. Avšak ani tyto znaky nejsou dostatečné pro spolehlivé určení kočky divoké nebo kočky domácí. Přesto, jak bylo očekáváno, jsou chlupy kočky divoké statisticky významně delší než chlupy mourovaté kočky domácí, a chlupy delší než $50 \mathrm{~mm}$ mohou být s jistotou prriřazeny kočce divoké. 


\section{A c know ledgements}

We thank JENS JAKoBITZ, MTD for providing the cat skins and all important data for the investigation. We also thank Andreas Weck-Heimann, Senckenber g Nat ur hist or ische Samml ungen Dr esden, for the training in the SEM and Hana DANEK, MTD for translation into Czech. We also thank several people and Institutions who sent in hairs of domestic cats for the first analyses: T. Dieckmann, C. Classen, Dresden, Tierpark Nordhorn. Last but not least, the helpful comments of the reviewers are thankfully acknowledged.

\section{REFERENCES}

Beaumont M., Barratt E. M., Gottelli D., Kitchener, A. C., Daniels, M. J., Pritchard, J. K. \& BruFORD M. W., 2001: Genetic diversity and introgression in the Scottish wildcat. Molecular Ecology, 10: $319-336$.

Buffon G. L. L., 1773: VIII. Die Katze. Pp.: 206-247. In: Buffon G. L. (eds.): Naturgeschichte der vierfüssigen Thiere. Mit Anmerkungen und Vermehrungen aus dem Französischen übersetzt. Joachim Pauli, Berlin, 308 pp.

Clutton-Brock J., 1999: A Natural History of Domesticated Mammals. Second Edition. Cambridge University Press, Cambridge, $238 \mathrm{pp}$.

Corbet L. K., 1979: Feeding Ecology and Social Organization of Wildcats (Felis silvestris) and Domestic Cats (Felis catus) in Scotland. Unpubl. PhD Thesis. University of Aberdeen, Scotland, 334 pp.

Daniels M. J., Balharry D., Hirst D., Kitchener A. C. \& Aspinall R. J., 1998: Morphological and pelage characteristics of wild living cats in Scotland - implications for defining the 'wildcat'. Journal of Zoology, London, 244: 231-247.

DharaiYa N. \& Soni V. C., 2012: Identification of hairs of some mammalian prey of large cats in Gir Protected Area, India. Journal of Threatened Taxa, 4: 2928-2932.

De MeiJere J. C. H., 1894: Über die Haare der Säugethiere - besonders über ihre Anordnung. Morphologisches Jahrbuch, 21: 312-424.

Driscoll C. A., Clutton-Brock, J., Kitchener A. C. \& O'brien S. J., 2009: The taming of the cat. Scientific American, 300: 68-75.

Driscoll C. A., Menotti-Raymond M., Roca A. L., Hupe K., Johnson W. E., Geffen E., Harley E. H., Delibes M., Pontier D., Kitchener A. C., Yamaguchi N., O’brien S. J. \& Macdonald D. W., 2007: The Near Eastern origin of cat domestication. Science, 317: 519-523.

ECKSTEIN K., 1919: Beiträge zur genaueren Kenntnis der Wildkatze. Archiv für Naturgeschichte, Abteilung A, 85(12): 1-59.

French D. D., Corbett L. K. \& Easterbee N., 1988: Morphological discriminants of Scottish wildcats (Felis silvestris), domestic cats (F. catus) and their hybrids. Journal of Zoology, London, 214: 235-259.

Hamilton E., 1896: The Wild Cat of Europe (Felis catus). First Edition. R. H. Porter, London, 132 pp.

HAUSMAN L. A., 1924: Further studies of the relationships of the structural characters of mammalian hair. American Naturalist, 58: 544-557.

Hofer H., 1914: Das Haar der Katze, seine Gruppenstellung und die Entwicklung der Beihaare. Archiv für Mikroskopische Anatomie, 85: 220-278.

HuPE K. \& SimON O., 2007: Die Lockstockmethode - eine nicht invasive Methode zum Nachweis der Europäischen Wildkatze (Felis silvestris silvestris). Informationsdienst Naturschutz Niedersachsen, 27: 66-69.

Kitchener A., 1991: The Natural History of the Wild Cats. First Edition. Cornell University Press, New York, $280 \mathrm{pp}$.

Kitchener A. C., Breitenmoser-Würsten Ch., Eizirik E., Gentry A., Werdelin L., Wilting A., Yamaguchi N., Abramov A. V., Christiansen P., Driscoll C., Duckworth J. W., Johnson W., Luo S.-J., Meijaard E., O’Donoghue P., Sanderson J., Seymour K., Bruford M., Groves C., Hoffmann M., Nowell K., Timmons Z. \& Toвe S. 2017: A Revised Taxonomy of the Felidae. The Final Report of the Cat Classification. Task Force of the IUCN/SSC Cat Specialist Group. Cat News Special Issue 11. Muri, Switzerland, 80 pp. 
KLeINSChmidT O., 1938: Die deutschen Wildkatzen. Falco, 34: 64-65.

KoнlhaAs J. J., 1794: Kurzgefaßte Naturgeschichte nach den drey Reichen der Natur - Ein Handbuch für Jünglinge und Erwachsene. First Edition. Schneider \& Weigel, Nürnberg, 388 pp.

KRatochvíl Z., 1973: Schädelkriterien der Wild- und Hauskatze (Felis silvestris silvestris Schreber 1777 und F. s. f. catus L. 1758). Acta Scientiarum Naturalium Academiae Scientiarum Bohemoslovacae Brno, n. s., 7: 1-50.

LAGOS L. \& BÁRCENA F., 2018: Spatial variability in wolf diet and prey selection in Galicia (NW Spain). Mammal Research, 63: 125-139.

Mattucci F., Galaverni M., Lyons L. A., Alves P. C., Randi E., Velli E., Pagani L. \& Caniglia R., 2019: Genomic approaches to identify hybrids and estimate admixture times in European wildcat populations. Scientific Reports, 9: 1-15.

Meyer W., Uhr G., Schwarz R. \& Radke B., 1982: Untersuchungen an der Haut der Europäischen Wildkatze (Felis silvestris Schreber) - II. Haarkleid. Zoologische Jahrbücher, Abteilung für Anatomie und Ontogenie der Tiere, 107: 205-234.

Meyer W., Seger H., Hülmann G. \& Neurand K., 1997a: A computer-assisted method for the determination of hair cuticula patterns in mammals. Berliner und Münchener Tierärztliche Wochenschrift, 110: $81-85$

Meyer W., Seger H., Hülmann G. \& Neurand K., 1997b: Untersuchungen zur Artbestimmung von Säugetieren anhand des Haarkutikulamusters - ein Vergleich von Haussäugetieren und ihren wilden Stammformen unter forensischer Sicht. Archiv für Kriminologie, 200: 45-55.

Meyer W., Hülmann G. \& Seger H., 2002a: REM-Atlas zur Haarkutikulastruktur mitteleuropäischer Säugetiere - SEM Atlas on the Hair Cuticle Structure of Central European Mammals. Schaper Alfeld, Hannover, $248 \mathrm{pp}$.

Meyer W., Schnapper A. \& Hülmann G., 2002b: The hair cuticle of mammals and its relationship to functions of the hair coat. Journal of Zoology, London, 256: 489-494.

Nussberger B., Greminger M. P., Grossen C., Keller L. F. \& Wandeler P., 2013: Development of SNP markers identifying European wildcats, domestic cats, and their admixed progeny. Molecular Ecology Resources, 13: 447-460.

Piechocki R., 1990: Die Wildkatze - Felis silvestris. First Edition. Die neue Brehm-Bücherei. Ziemsen, Wittenberg Lutherstadt, $232 \mathrm{pp}$.

RAGNi B. \& Possenti M., 1996: Variability of coat-colour and markings system in Felis silvestris. Italian Journal of Zoology, 63: 285-292.

Randi E., Pierpaoli M., Beaumont M., Ragni B. \& Sforzi A., 2001: Genetic identification of wild and domestic cats (Felis silvestris) and their hybrids using Bayesian clustering methods. Molecular Biology and Evolution, 18: 1679-1693.

SARI A. \& ARPACIK A., 2018: Morphological hair identification key of common mammals in Turkey. Applied Ecology and Environmental Research, 16: 4593-4603.

Schreber J. C. D., 1777: Die Säugthiere in Abbildungen nach der Natur, mit Beschreibungen. Third Edition. Walther, Erlangen, 810 pp.

SCHRÖDER A., 1930: Ist die Unterscheidung von Menschen- und Tierhaaren durch Untersuchung der Cuticula möglich? Deutsche Zeitschrift für die Gesamte Gerichtliche Medizin, 15: 127-148.

SládeK J., 1976: Farbanomalien bei der westkarpatischen Population der Wildkatze (Felis silvestris Schreber 1777). Lynx, n. s., 18: 73-83.

Stefen C. \& Görner M., 2009: Die Wildkatze (Felis silvestris Schreber, 1777) in Deutschland und Mitteleuropa - zum Stand der Forschung und Konsequenzen für den Schutz. Säugetierkundliche Informationen, 7: 3-216.

Steyer K., Simon O., Kraus R. H. S., HaAse P. \& Nowak, C., 2013: Hair trapping with val er ian-tr eat ed lure sticks as tool for genetic wildcat monitoring in low-density habitats. European Journal of Wildlife Research, 59: 39-46.

TeErink B. J., 1991: Hair of West-European Mammals - Atlas and Identification Key. First Edition. Cambridge University Press, Cambridge, 224 pp. 
Tо́тн M., 2017: Hair and Fur Atlas of Central European Mammals. Pars Ltd, Nagykovácsi, 307 pp.

Vogt D., 1984: Merkmalsbewertung sowie Verbreitung und Habitate der Wildkatze (Felis silvestris) in den linksrheinischen Landesteilen von Rheinland-Pfalz. Unpubl. $\mathrm{PhD}$ thesis. Universität Heidelberg, Heidelberg, $179 \mathrm{pp}$.

WALDEYER W., 1884: Atlas der menschlichen und tierischen Haare sowie der ähnlichen Fasergebilde. Schauenburg, Lahr, 195 pp.

Wozencraft W. C., 1993: Order Carnivora. Pp.: 279-348. In: Wilson D. E. \& Reeder D. A.(eds.): Mammal Species of the World. A Taxonomic and Geographic Reference. Smithsonian Institution Press, Washington, $1312 \mathrm{pp}$. 